\title{
Table of Contents
}

Elinor Shaffer

Foreword $\ldots \ldots \ldots \ldots \ldots \ldots \ldots \ldots \ldots \ldots \ldots \ldots \ldots \ldots, \ldots \ldots \ldots$

Maike Oergel

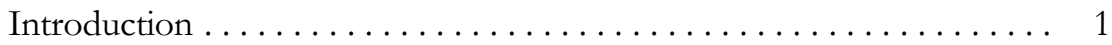

Imke Heuer

'That war with softer cares may be united': Harriet Lee,

Georgiana Duchess of Devonshire, the Thirty Years' War,

and the Politics of Adaptation ........................ 9

Susanne Kord

From Sentiment to Sexuality: English Werther-Stories,

the French Revolution, and German Vampires................. 25

Barry Murnane

Radical Translations: Dubious Anglo-German Cultural Transfer

in the 1790 s..................................... 44

W. Daniel Wilson

Goethe and Schiller, Peasants and Students: Weimar and

the French Revolution .............................. 61

Birgit Tautz

Revolution, Abolition, Aesthetic Sublimation: German Responses

to News from France in the $1790 \mathrm{~s}$. . . . . . . . . . . . . . . . . . 72

Renata Schellenberg

Print and Preserve: Periodicals in Late Eighteenth-Century Germany. . 88

Christian Deuling

Aesthetics and Politics in the Journal London und Paris (1798-1815). . . . 102

Maike Oergel

Changing Authorities on HMS Bounty: The Public Images of

William Bligh and Fletcher Christian in the Context of Late

Eighteenth-Century Political and Intellectual Conditions ............ 119 
Judith Still

A Fictional Response to the Categorical Imperative:

Women Refugees, Servants, and Slaves in Charrière's Trois Femmes . . . . 142

Melissa Deininger

Sade, Revolution, and the Boundaries of Freedom............ 157

Jakob Ladegaard

Impossible Crossings: Friedrich Hölderlin's Hyperion and

the Aesthetic Foundation of Democracy. . . . . . . . . . . . . 170

Ian Macgregor Morris and Uta Degner

Evénements de Circonstance: The Classical Tradition in the

Age of Revolution. ............................ 186

Peter Krilles

Detours of Knowledge: Aspects of Novalis' Aesthetic Epistemology . . 204

Dirk Göttsche

Challenging Time(s): Memory, Politics, and the Philosophy of Time

in Jean Paul's Quintus Fixlein . . . . . . . . . . . . . . . . . . . . . . . 219

David McCallam

Xavier de Maistre and Angelology.........................239

Sibylle Erle

Introducing the Songs with Inspiration: William Blake, Lavater, and the Legacy of Felix Hess .......................... 251

The Contributors .................................2270 